\title{
Synthesis and Thermal Stability of New Ni-Based Bulk Glassy Alloy with Excellent Mechanical Properties
}

\author{
Katuyoshi Arai ${ }^{1, * 1}$, Wei Zhang ${ }^{2, * 2}$, Fei $\mathrm{Jia}^{2}$ and Akihisa Inoue ${ }^{2}$ \\ ${ }^{1}$ Graduate school, Tohoku University, Sendai 980-8577, Japan \\ ${ }^{2}$ Institute for Materials Research, Tohoku University, Sendai 980-8577, Japan
}

\begin{abstract}
The thermal stability, glass-forming ability (GFA) and mechanical properties of the Ni-Ta-Ti and Ni-Ta-Ti-Zr glassy alloys have been investigated. As the Ti content increases, the supercooled liquid region $\Delta T_{x}\left(=T_{x}-T_{g}\right)$ and reduced glass transition temperature $\left(T_{g} / T_{l}\right)$ of $\mathrm{Ni}_{60} \mathrm{Ta}_{40-x} \mathrm{Ti}_{x}$ glassy alloys increase, showing maximum values of $63 \mathrm{~K}$ at $20 \% \mathrm{Ti}$ and 0.59 at 25 at $\% \mathrm{Ti}$, respectively, and then gradually decrease. The addition of $\mathrm{Zr}$ to Ni-Ta-Ti alloys is effective for the increase in $\Delta T_{x}$ and $T_{g} / T_{l}$. The maximum $\Delta T_{x}$ and $T_{g} / T_{l}$ values of $73 \mathrm{~K}$ and 0.60 , respectively, are obtained for $\mathrm{Ni}_{60} \mathrm{Ta}_{15} \mathrm{Ti}_{20} \mathrm{Zr}_{5}$ alloy. The Ni-Ta-Ti-Zr glassy alloys were formed in the rod form with diameters of over $1.0 \mathrm{~mm}$ by copper mold casting. The Ni-Ta-Ti-Zr bulk glassy alloys exhibit excellent mechanical properties, i.e., the compressive fracture strength $\left(\sigma_{c, f}\right)$ of $3180-3220 \mathrm{MPa}$ and the compressive plastic elongation $\left(\varepsilon_{c, p}\right)$ of $0.2-0.4 \%$. [doi:10.2320/matertrans.47.2358]
[
\end{abstract}

(Received April 25, 2006; Accepted July 18, 2006; Published September 15, 2006)

Keywords: nickel-based alloy, thermal stability, glass-forming ability, bulk glassy alloy, mechanical property

\section{Introduction}

It is known that amorphous alloys have characteristic physical and chemical properties such as high strength, high corrosion resistance and good soft magnetic properties, which are significantly different from the corresponding crystalline alloys. ${ }^{1)}$ However, the requirement of rapid solidification has led to strict limitation of their material shape to ribbons, wires and powders and its limitation has restricted further extension of their application fields. Since the findings of the stabilization of supercooled liquid in multi-component alloys consisting only of metallic elements in 1988, followed by the syntheses of bulk glassy alloys by use of the stabilization of supercooled liquid, much effort has been devoted to develop a new bulk glassy alloy exhibiting high glass-forming ability (GFA) and useful engineering properties. The development of bulk glassy alloys was focused on $\mathrm{Mg}_{-}{ }^{2)}$ lanthanide-3) and early transition metal (ETM)-based alloy systems ${ }^{4,5)}$ in the early stage period between 1988 and 1993, and then much attention has been paid to the late transition metal (LTM)-based bulk glassy alloys such as $\mathrm{Fe}-,{ }^{6-9)} \mathrm{Co}-,{ }^{10,11)} \mathrm{Cu}^{12-18)}$ and $\mathrm{Ni}^{-19-24)}$ based alloys because of their more importance in engineering aspects. The advantage points for the LTM bulk glassy alloys include higher strength,,11-24) and good soft magnetic properties, ${ }^{8-11)}$ excellent corrosion resistance, ${ }^{23)}$ and lower materials cost. ${ }^{6-9,12,14)}$ It is noticed that high fracture strength with good toughness can be obtained for the LTM-based bulk glassy alloys consisting only of metallic elements, such as $\mathrm{Cu}^{-12-18)}$ and $\mathrm{Ni}^{20,21,23-25)}$ based systems, and the $\mathrm{Ni}-\mathrm{Nb}$ based bulk glassy alloy has the highest fracture strength.

The synthesis of Ni-Nb-based bulk glassy alloys has been reported in $2002 .^{20)}$ The Ni-based bulk glassy alloy rods with diameters of $1.5-3 \mathrm{~mm}$ were fabricated in the $\mathrm{Ni}-\mathrm{Nb}-\mathrm{Ti}$ ternary and $\mathrm{Ni}-\mathrm{Nb}$-Ti-based multi-component alloys, and exhibited high strength of $\sim 3080 \mathrm{MPa},{ }^{20,21,24,25)}$ distinct

\footnotetext{
${ }^{* 1}$ Graduate Student, Tohoku University

${ }^{* 2}$ Corresponding author. E-mail: wzhang@imr.tohoku.ac.jp
}

plastic strains, high thermal stability, and excellent corrosion resistance in aggressive acids. ${ }^{26)}$ In addition, their alloys are expected to replace the conventional graphite bipolar plates in fuel cells. Recently, we have investigated the effect of different elements on the corrosion resistance of the Ni-Nbbased glassy alloys, and found that substitution of $\mathrm{Ta}$ for $\mathrm{Nb}$ in the Ni-Nb-based glassy alloys was very effective for increasing the corrosion resistance in fluoride containing acid solution at a high temperature. ${ }^{27)}$ However, little is known about the effect of substitution of $\mathrm{Ta}$ for $\mathrm{Nb}$ on the thermal stability of the supercooled liquid, glass-forming ability and mechanical properties of the Ni-Ta-based glassy alloys. The heats of mixing in the $\mathrm{Ni}-\mathrm{Nb}$ and $\mathrm{Ni}$-Ta pairs as well as the atomic sizes of $\mathrm{Ta}$ and $\mathrm{Nb}$ are similar with each other. ${ }^{28,29)}$ In addition, Ta metal has a much higher melting temperature than $\mathrm{Nb}$. Therefore, a new type of Ni-Ta-based bulk glassy alloy is expected to exhibit higher mechanical strength and thermal stability than those of $\mathrm{Ni}-\mathrm{Nb}$-based bulk glassy alloys. This paper presents the thermal stability, glassforming ability (GFA) and mechanical properties of the $\mathrm{Ni}_{60} \mathrm{Ta}_{40-x} \mathrm{Ti}_{x}(x=0$ to 40$)$ and $\mathrm{Ni}_{60} \mathrm{Ta}_{40-x-y} \mathrm{Ti}_{x} \mathrm{Zr}_{y}(y=0$ to 30) glassy alloys. The reasons for the high thermal stability and mechanical properties for the Ni-Ta-based bulk glassy alloys are also discussed.

\section{Experimental Procedure}

Multi-component Ni-based alloy ingots with nominal composition of $\mathrm{Ni}_{60} \mathrm{Ta}_{40-x} \mathrm{Ti}_{x}(x=0$ to 40$)$ and $\mathrm{Ni}_{60}{ }^{-}$ $\mathrm{Ta}_{40-x-y} \mathrm{Ti}_{x} \mathrm{Zr}_{y}(y=0$ to 30$)$ were prepared by arc melting the mixtures of pure $\mathrm{Ni}, \mathrm{Ta}, \mathrm{Zr}$ and $\mathrm{Ti}$ metals in an argon atmosphere. The purity of metals was over 99.5 mass $\%$. Alloy ingots were re-melted five times to ensure chemical homogeneity. The mass losses were measured for each ingot after melting and were less than 0.1 mass $\%$. The glassy alloy was produced by copper mold casting for bulk cylindrical rods with diameters up to $1.5 \mathrm{~mm}$ and by melt spinning for ribbons with a cross section of $0.02 \times 1.2 \mathrm{~mm}^{2}$. The glassy phase was identified by X-ray diffractometer using $\mathrm{Cr}-\mathrm{K} \alpha$ 


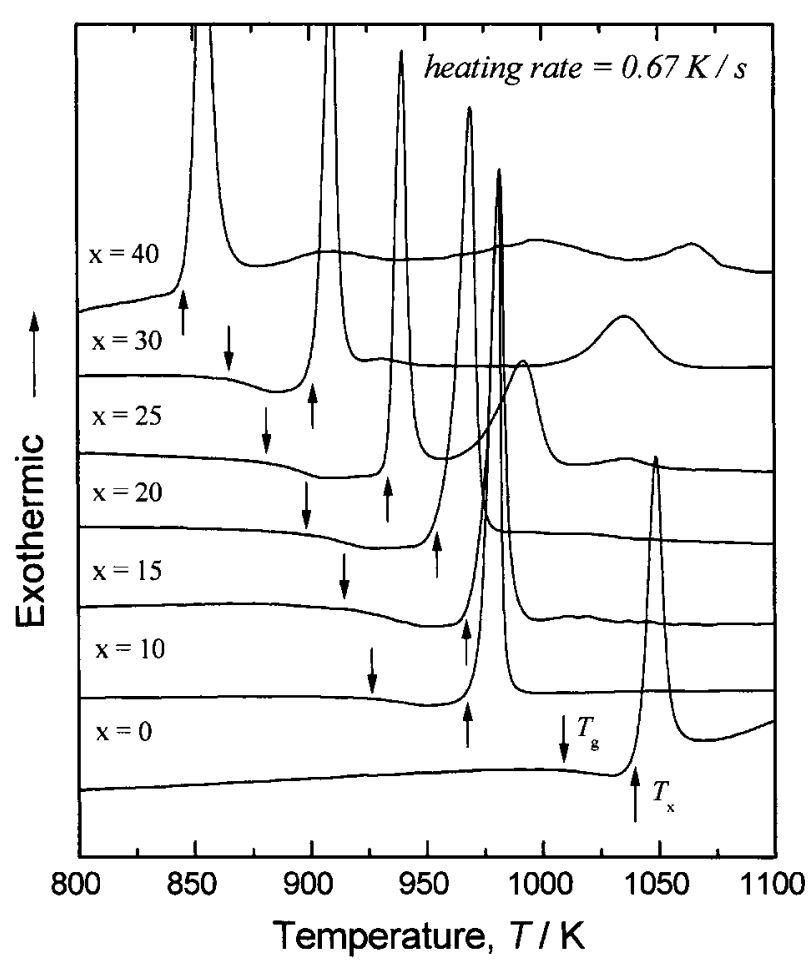

Fig. 1 DSC curves of melt-spun $\mathrm{Ni}_{60} \mathrm{Ta}_{40-x} \mathrm{Ti}_{x}(x=0$ to 40 at $\%)$ glassy alloys.

radiation and thermal stability was examined by differential scanning calorimetry (DSC) at a heating rate of $0.67 \mathrm{~K} / \mathrm{s}$. The melting and liquidus temperatures were measured with a differential thermal analyzer (DTA) at a heating rate of $0.33 \mathrm{~K} / \mathrm{s}$. Mechanical properties were measured with an Instron testing machine. The gauge dimension of specimens was $1 \mathrm{~mm}$ in diameter and $2 \mathrm{~mm}$ in height for compressive test and the strain rate was $5 \times 10^{-4} \mathrm{~s}^{-1}$. The fracture surface was examined by scanning electron microscopy (SEM).

\section{Results}

The X-ray diffraction patterns and DSC curves showed that the melt-spun $\mathrm{Ni}_{100-x} \mathrm{Ta}_{x}(x=35$ to 45$)$ ribbons were composed of a glassy single phase. However, the supercooled liquid region $\left(\Delta T_{x}\right)$ and the reduced glass transition temperature $\left(T_{g} / T_{l}\right)$ are below $40 \mathrm{~K}$ and 0.58 , respectively, indicating that the Ni-Ta binary glassy alloys do not have high thermal stability of supercooled liquid and high GFA. ${ }^{30,31)}$

We examined the effect of $\mathrm{Ti}$ addition on the thermal stability of supercooled liquid in the glassy alloy series of $\mathrm{Ni}_{60} \mathrm{Ta}_{40-x} \mathrm{Ti}_{x}$. Figure 1 shows DSC curves of the melt-spun $\mathrm{Ni}_{60} \mathrm{Ta}_{40-x} \mathrm{Ti}_{x} \quad(x=0$ to 40$)$ glassy alloys. The glass transition temperature $\left(T_{g}\right)$ and crystallization temperature $\left(T_{x}\right)$ decrease from 1005 to $861 \mathrm{~K}$ and 1042 to $903 \mathrm{~K}$, respectively, with increasing $\mathrm{Ti}$ content from 0 to 30 at $\%$, while the $\Delta T_{x}$ increases from 38 to $63 \mathrm{~K}$ with increasing $\mathrm{Ti}$ content from 0 to 20 at $\%$ and then decreases to $42 \mathrm{~K}$ with a further increase in Ti content to 30 at $\%$. No glass transition is observed for $\mathrm{Ni}_{60} \mathrm{Ti}_{40}$. We further measured the liquidus temperature $\left(T_{l}\right)$ by DTA. The $T_{l}$ and $T_{g} / T_{l}$ were plotted as a function of $\mathrm{Ti}$ content for the $\mathrm{Ni}_{60} \mathrm{Ta}_{40-x} \mathrm{Ti}_{x}$ glassy alloys in Fig. 2. It can be seen that the $T_{l}$ values of the ternary alloys
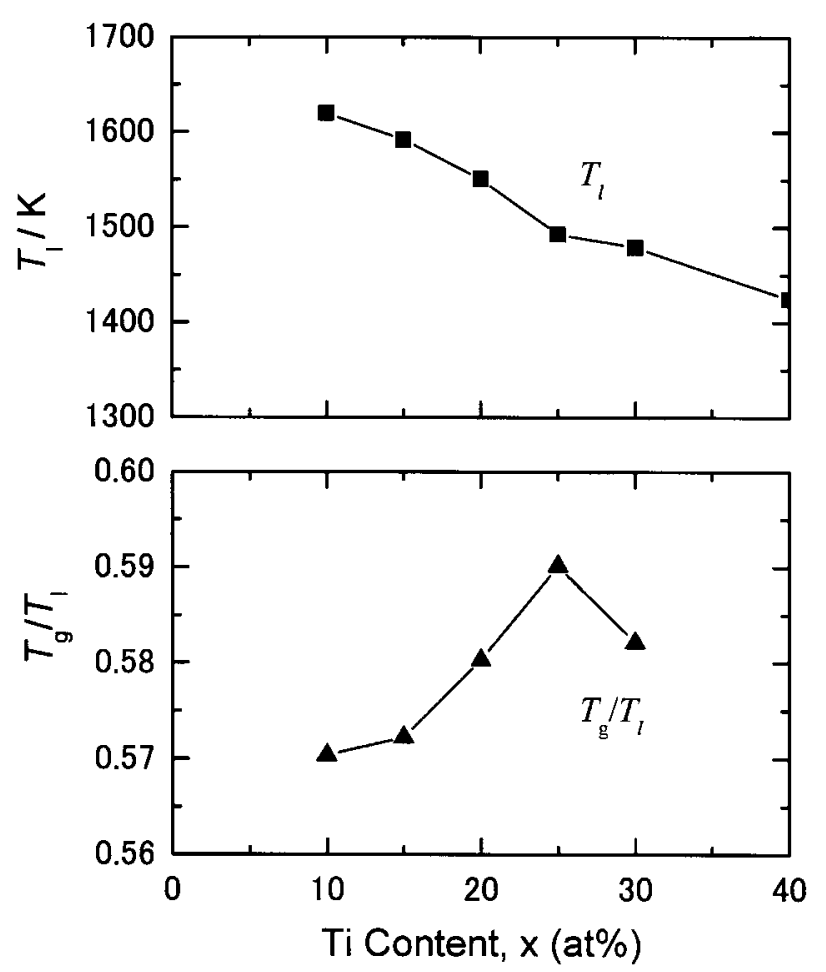

Fig. 2 Liquidus temperature $\left(T_{l}\right)$ and reduced glass transition temperature $\left(T_{g} / T_{l}\right)$ as a function of $\mathrm{Ti}$ content for the $\mathrm{Ni}_{60} \mathrm{Ta}_{40-x} \mathrm{Ti}_{x}(x=10$ to 40 at $\%$ ) glassy alloys.

significantly decrease with increasing Ti content. However, the $T_{g} / T_{l}$ increases from 0.57 to 0.59 with increase of $\mathrm{Ti}$ content from 10 to 25 at $\%$, and then decreases with a further increasing Ti content. The large $\Delta T_{x}$ values exceeding $60 \mathrm{~K}$ and high $T_{g} / T_{l}$ above 0.58 are simultaneously obtained in the $\mathrm{Ti}$ concentration range of 20-25 at\%. It is therefore concluded that the addition of $\mathrm{Ti}$ to Ni-Ta binary glassy alloys is effective in increaseing the stability of supercooled liquid and GFA. We examined the GFA of Ni-Ta-Ti ternary alloys by copper mold casting, but the critical rod diameter for formation of the glassy phase was below $1.0 \mathrm{~mm}$.

We further examined the effect of $\mathrm{Zr}$ addition on the thermal stability of supercooled liquid and GFA of the Ni-TaTi ternary glassy alloys. Figure 3 shows DSC curves of the melt-spun $\mathrm{Ni}_{60} \mathrm{Ta}_{15} \mathrm{Ti}_{25-x} \mathrm{Zr}_{x}$ ( $x=0$ to 25$)$ glassy alloys. It can be seen that the $\Delta T_{x}$ increases with increasing $\mathrm{Zr}$ content from 0 to 5 at $\%$, and then decreases with a further increase in $\mathrm{Zr}$ content to $25 \mathrm{at} \%$. The $5 \mathrm{at} \% \mathrm{Zr}$ alloy shows a maximum $\Delta T_{x}$ of $73 \mathrm{~K}$. Figure 4 shows the changes in the $T_{l}$ and $T_{g} / T_{l}$ with $\mathrm{Zr}$ content for the $\mathrm{Ni}_{60} \mathrm{Ta}_{15} \mathrm{Ti}_{25-x} \mathrm{Zr}_{x}(x=0$ to 25) and $\mathrm{Ni}_{60} \mathrm{Ta}_{20} \mathrm{Ti}_{20-x} \mathrm{Zr}_{x}$ ( $x=0$ to 20 ) glassy alloys. The lowest $T_{l}$ at 5 at $\% \mathrm{Zr}$ causes the highest $T_{g} / T_{l}$ of 0.60 for both the alloy series, and the further increase in $\mathrm{Zr}$ content results in a decrease in $T_{g} / T_{l}$. The large $\Delta T_{x}$ of over $60 \mathrm{~K}$ as well as the high $T_{g} / T_{l}$ of 0.60 for the $\mathrm{Ni}_{60} \mathrm{Ta}_{20} \mathrm{Ti}_{15} \mathrm{Zr}_{5}$ and $\mathrm{Ni}_{60} \mathrm{Ta}_{15^{-}}$ $\mathrm{Ti}_{20} \mathrm{Zr}_{5}$ alloys indicates that the choice of their alloy compositions may lead to the formation of bulk glassy alloys by copper mold casting.

The cast $\mathrm{Ni}_{60} \mathrm{Ta}_{20} \mathrm{Ti}_{15} \mathrm{Zr}_{5}$ and $\mathrm{Ni}_{60} \mathrm{Ta}_{15} \mathrm{Ti}_{20} \mathrm{Zr}_{5}$ rods with a diameter of $1.0 \mathrm{~mm}$ were produced. The XRD patterns of the alloy rods were shown in Fig. 5. The XRD patterns of the rods consist only of a broad peak, and no diffraction peak 




Fig. 3 DSC curves of melt-spun $\mathrm{Ni}_{60} \mathrm{Ta}_{15} \mathrm{Ti}_{25-x} \mathrm{Zr}_{x} \quad(x=0$ to 25 at $\%)$ glassy alloys.
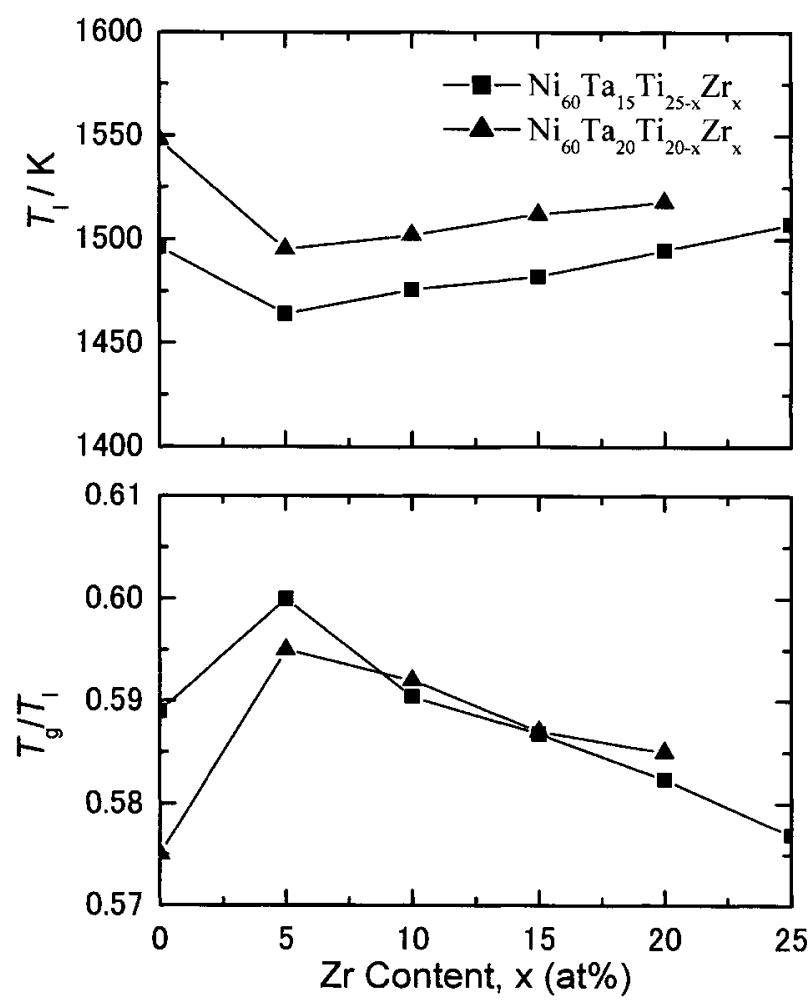

Fig. 4 Liquidus temperature $\left(T_{l}\right)$ and reduced glass transition temperature $\left(T_{g} / T_{l}\right)$ as a function of $\mathrm{Ti}$ content for the $\mathrm{Ni}_{60} \mathrm{Ta}_{15} \mathrm{Ti}_{25-x} \mathrm{Zr}_{x}$ ( $x=0$ to 25) and $\mathrm{Ni}_{60} \mathrm{Ta}_{20-x} \mathrm{Ti}_{20-x} \mathrm{Zr}_{x}$ ( $x=0$ to 20$)$ glassy alloys.

corresponding to a crystalline phase is seen, indicating that a glassy phase is formed. The further increase in the rod diameter to $1.5 \mathrm{~mm}$ resulted in the precipitation of crystalline phases. It is therefore concluded that the critical rod diameter for formation of the glassy phase lies between 1.0 and

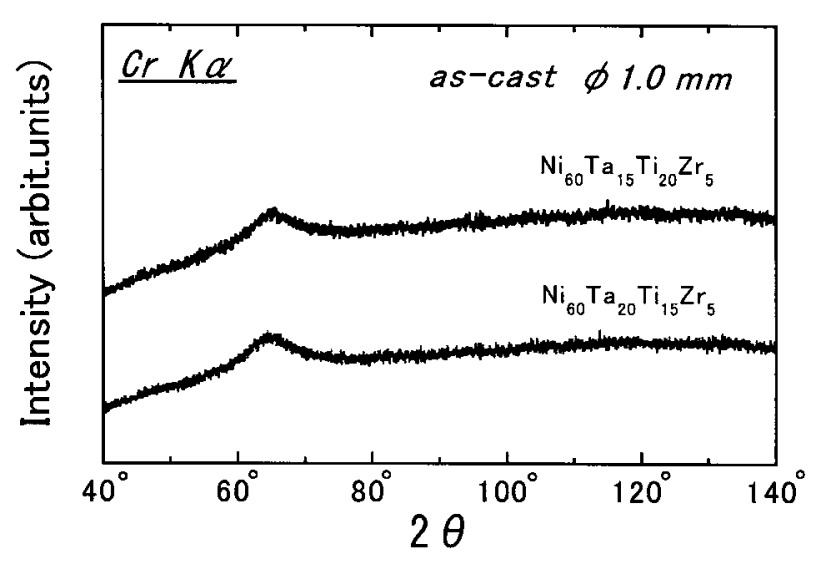

Fig. 5 X-ray diffraction patterns of $\mathrm{Ni}_{60} \mathrm{Ta}_{20} \mathrm{Ti}_{15} \mathrm{Zr}_{5}$ and $\mathrm{Ni}_{60} \mathrm{Ta}_{15} \mathrm{Ti}_{20} \mathrm{Zr}_{5}$ alloy rods with a diameter of $1.0 \mathrm{~mm}$.



Fig. 6 Compressive stress-elongation curves of cast $\mathrm{Ni}_{60} \mathrm{Ta}_{20} \mathrm{Ti}_{15} \mathrm{Zr}_{5}$ and $\mathrm{Ni}_{60} \mathrm{Ta}_{15} \mathrm{Ti}_{20} \mathrm{Zr}_{5}$ glassy rods with diameters of $1.0 \mathrm{~mm}$.

$1.5 \mathrm{~mm}$. We also measured the $T_{g}, T_{x}$ and heat of crystallization $\Delta H_{c}$ of these cast alloy rods on the basis of DSC curves. It was confirmed that the $T_{g}, T_{x}$ and $\left(\Delta H_{c}\right)$ are nearly the same between the bulk and ribbon samples, being consistent with the result obtained by XRD.

Figure 6 shows the stress-elongation curves under a compressive applied load for the bulk glassy $\mathrm{Ni}_{60} \mathrm{Ta}_{15} \mathrm{Ti}_{20} \mathrm{Zr}_{5}$ and $\mathrm{Ni}_{60} \mathrm{Ta}_{20} \mathrm{Ti}_{15} \mathrm{Zr}_{5}$ alloy rods of $1.0 \mathrm{~mm}$ in diameter. The alloys exhibit excellent mechanical properties. That is, the compressive fracture strength $\left(\sigma_{c, f}\right)$ and compressive plastic elongation $\left(\varepsilon_{c, p}\right)$ are $3180 \mathrm{MPa}$ and $0.4 \%$, respectively, for the former alloy, and $3220 \mathrm{MPa}$ and $0.2 \%$, respectively, for the latter alloy. The fracture behavior and fracture surface appearance are exemplified for the $\mathrm{Ni}_{60} \mathrm{Ta}_{20} \mathrm{Ti}_{15} \mathrm{Zr}_{5}$ glassy alloy rod in Fig. 7. The fracture occurs along the maximum shear plane, which is declined by about 40 degrees to the direction of applied load (Fig. 7(a)), and the fracture surface consists mainly of a well-developed vein pattern (Fig. 7(b)) typical to other bulk glassy alloys with good ductility. ${ }^{20,30)}$ Many shear bands which are marked with arrows are also observed on the rod surface (Fig. 7(c)). The appearance of the plastic strain can thus be attributed to the generation of the shear bands. 

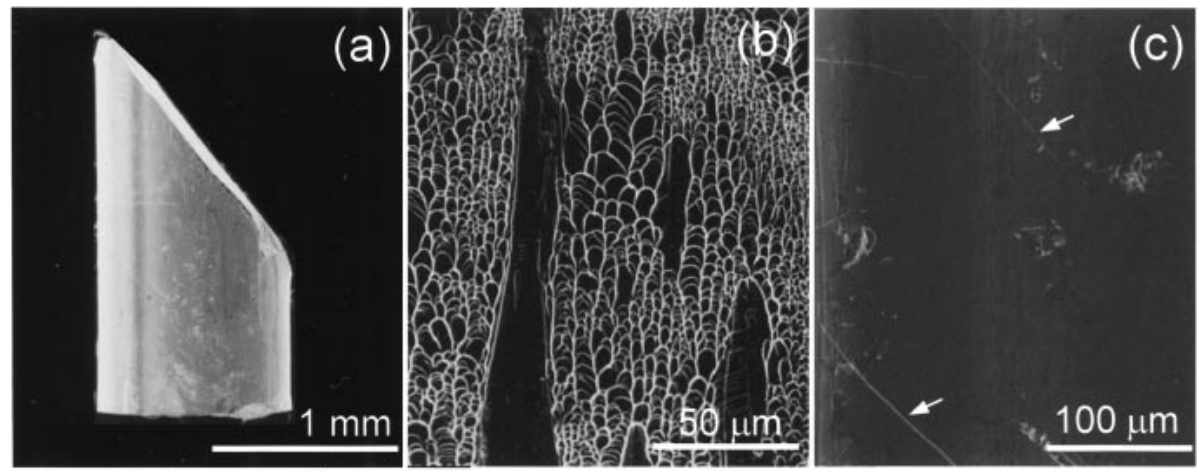

Fig. 7 Fracture surface appearance of the cast glassy $\mathrm{Ni}_{60} \mathrm{Ta}_{20} \mathrm{Ti}_{15} \mathrm{Zr}_{5}$ alloy rod.

\section{Discussion}

We discuss the reason for the significant effect of $\mathrm{Ti}$ and $\mathrm{Zr}$ additions on the improvement of thermal stability and glassforming ability of the Ni-Ta glassy alloys. It has been reported that the high thermal stability of supercooled liquid and high GFA leading to the formation of a bulk glassy alloy is obtained in the multi-component alloy systems satisfying the following three empirical component rules, ${ }^{30,31)}$ i.e., (1) multi-component consisting of more than three elements, (2) significant atomic size mismatches above $12 \%$ among the main three elements, and (3) negative heats of mixing among the main elements. In the $\mathrm{Ni}-\mathrm{Ta}-\mathrm{Ti}-\mathrm{Zr}$ system, their atomic sizes change in the order of $\mathrm{Zr}(0.162 \mathrm{~nm}) \gg \mathrm{Ta}(0.147$ $\mathrm{nm})>\mathrm{Ti}(0.143 \mathrm{~nm}) \gg \mathrm{Ni}(0.125 \mathrm{~nm}) .{ }^{28)}$ Furthermore, the heats of mixing have been estimated to be $-29 \mathrm{~kJ} / \mathrm{mol}$ for $\mathrm{Ni}-\mathrm{Ta},-49 \mathrm{~kJ} / \mathrm{mol}$ for $\mathrm{Ni}-\mathrm{Zr}$ and $-39 \mathrm{~kJ} / \mathrm{mol}$ for $\mathrm{Ni}-\mathrm{Ti}^{29}{ }^{29}$ The present combinations of atomic sizes can produce an efficiently dense random packing structure, which is often associated with low interfacial energy and high viscosity of liquids. In this glassy structure, the atomic diffusivity is also reduced, leading to the suppression of nucleation and growth reactions of a crystalline phase from liquid. In addition, the formation of the unique glassy structure is also attributed to the existence of the strongly attractive bonding $\mathrm{Ni}-\mathrm{Ta}, \mathrm{Ni}-\mathrm{Zr}$ and Ni-Ti pairs, which can improve the local packing efficiency and restrain long range diffusion of atoms. Thus, these factors lead to the high thermal stability of the supercooled liquid against crystallization. ${ }^{31)}$

It is also noticed that the compressive fracture strength $\sigma_{c, f}$ is much higher than those for the other metal-metal type of bulk glassy alloys, e.g., 600-900 MPa for Ln- and Mg- based bulk glassy alloys, ${ }^{32,33)} 1500-2500 \mathrm{MPa}$ for $\mathrm{Zr}$ - and $\mathrm{Cu}$ based bulk glassy alloys, ${ }^{12-14,16,31)}$ and $2700-3085 \mathrm{MPa}$ for other Ni-based bulk glassy alloys. ${ }^{21,22,25)}$ With the aim of investigating the origin for the high $\sigma_{c, f}$ of the Ni-based bulk glassy alloys, the relation between $\sigma_{c, f}$ and $T_{g}$ for typical bulk glassy alloys including the present $\mathrm{Ni}-\mathrm{Ta}-\mathrm{Ti}-\mathrm{Zr}$ glassy alloys is shown in Fig. 8. One can see a clear tendency for $\sigma_{c, f}$ to increase with increasing $T_{g}$. Considering the previous concept that the $T_{g}$ of the glassy alloys reflects the bonding force among the constituent elements, ${ }^{34)}$ it is concluded that the high $\sigma_{c, f}$ value of the present Ni-based Ni-Ta-Ti-Zr bulk glassy alloy originates from the strong bonding nature among the constituent elements.

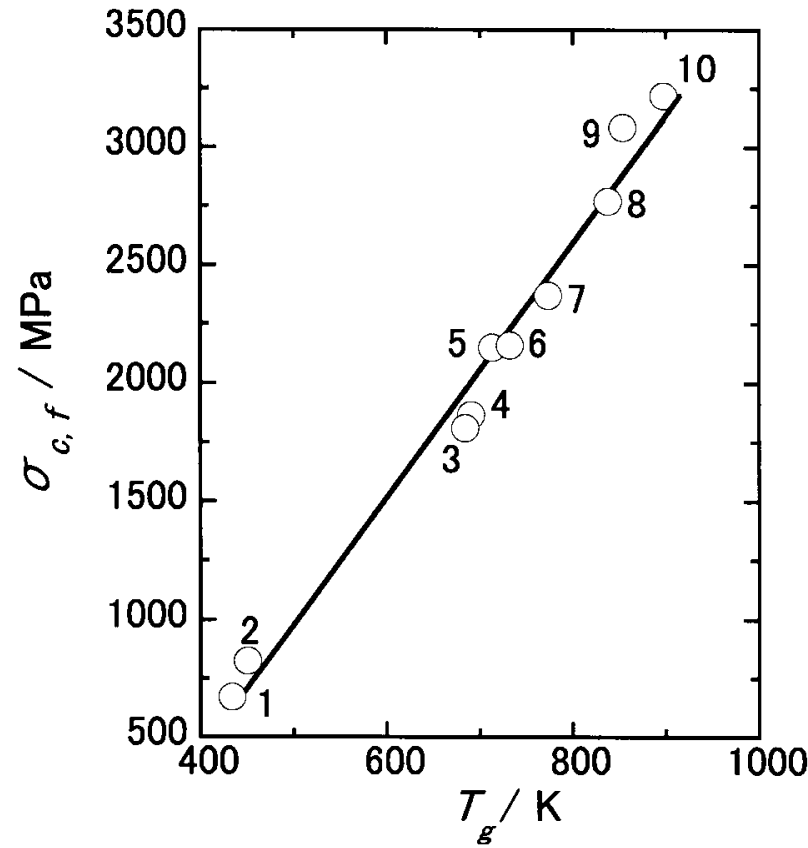

Fig. 8 Relation between compressive fracture strength $\left(\sigma_{c, f}\right)$ and glass transition temperature $\left(T_{g}\right)$ for the $\mathrm{Ni}_{60} \mathrm{Ta}_{20} \mathrm{Ti}_{15} \mathrm{Zr}_{5}$ glassy alloy rod. The data of other metal-metal type of bulk glassy alloys are also shown for comparison. (1) $\mathrm{La}_{55} \mathrm{Al}_{25} \mathrm{Ni}_{10} \mathrm{Cu}_{5} \mathrm{Co}_{5}$; (2) $\mathrm{Mg}_{80} \mathrm{Cu}_{10} \mathrm{Y}_{10}$; (3) $\mathrm{Zr}_{55} \mathrm{Al}_{10^{-}}$ $\mathrm{Ni}_{5} \mathrm{Cu}_{30}$; (4) $\mathrm{Cu}_{45} \mathrm{Zr}_{45} \mathrm{Ag}_{10}$; (5) $\mathrm{Cu}_{60} \mathrm{Zr}_{30} \mathrm{Ti}_{10}$; (6) $\mathrm{Cu}_{50} \mathrm{Hf}_{45} \mathrm{Al}_{5}$; (7) $\mathrm{Ni}_{40} \mathrm{Ti}_{20} \mathrm{Zr}_{25} \mathrm{Al}_{10}$; (8) $\mathrm{Ni}_{60} \mathrm{Nb}_{20} \mathrm{Ti}_{15} \mathrm{Zr}_{5}$; (9) $\mathrm{Ni}_{60} \mathrm{Nb}_{25} \mathrm{Ti}_{15}$; (10) $\mathrm{Ni}_{60} \mathrm{Ta}_{20^{-}}$ $\mathrm{Ti}_{15} \mathrm{Zr}_{5}$.

\section{Summary}

The thermal stability and GFA of Ni-Ta-based glassy alloys increase by the addition of $\mathrm{Ti}$ and $\mathrm{Zr}$. The large $\Delta T_{x}$ exceeding $60 \mathrm{~K}$ and high $T_{g} / T_{l}$ of over 0.59 were obtained in a composition range of $15-25$ at $\% \mathrm{Ta}, 20-25$ at\% $\mathrm{Ti}$, and 510 at\% Zr. The new Ni-based bulk glassy alloys with a diameter of $1.0 \mathrm{~mm}$ were fabricated for the $\mathrm{Ni}_{60} \mathrm{Ta}_{20} \mathrm{Ti}_{15} \mathrm{Zr}_{5}$ and $\mathrm{Ni}_{60} \mathrm{Ta}_{15} \mathrm{Ti}_{20} \mathrm{Zr}_{5}$ alloys. The Ni-Ta-Ti-Zr bulk glassy alloys exhibit excellent mechanical properties, i.e., compressive fracture strength of $\sim 3180-3220 \mathrm{MPa}$, and plastic elongation of $\sim 0.2-0.4 \%$. The fracture strength reported in this paper may be the highest among the ductile bulk glassy alloys ever obtained. 


\section{Acknowledgements}

This work was financially supported by Development Project on Advanced Metallic Glasses, Inorganic Materials and Joining Technology from the Ministry of Education, Science, Sports, and Culture of Japan.

\section{REFERENCES}

1) F. E. Luborsky (Ed.): Amorphour Metallic Alloys, (Butterworths, London, 1983).

2) A. Inoue, K. Ohtera, K. Kita and T. Masumoto: Jpn. J. Appl. Phys. 27 (1988) L2248-L2251.

3) A. Inoue, T. Zhang and T. Masumoto: Mater. Trans., JIM 30 (1989) 965-972.

4) A. Inoue, T. Zhang and T. Masumoto: Mater. Trans., JIM 31 (1990) 177-183.

5) A. Peker and W. L. Johnson: Appl. Phys. Lett. 63 (1993) 2342-2344.

6) A. Inoue and J. S. Gook: Mater. Trans., JIM 36 (1995) 1180-1183.

7) A. Inoue, T. Zhang and A. Takeuchi: Appl. Phys. Lett. 71 (1997) 464 466.

8) W. Zhang and A. Inoue: Mater. Trans., JIM 41 (2000) 1679-1682.

9) A. Inoue and B. Shen: Mater. Trans. 43 (2002) 766-769.

10) T. Itoi and A. Inoue: Mater. Trans., JIM 41 (2000) 1256-1262.

11) A. Inoue, B. Shen, H. Koshiba, H. Kato and A. Yavari: Acta Mater. 52 (2004) 1631-1637.

12) A. Inoue, W. Zhang, T. Zhang and K. Kurosaka: Acta Mater. 49 (2001) $2645-2652$.
13) A. Inoue, W. Zhang, T. Zhang and K. Kurosaka: J. Mater. Res. 16 (2001) 2836-2844.

14) A. Inoue and W. Zhang: Mater. Trans. 43 (2002) 2921-2925.

15) A. Inoue and W. Zhang: J. Mater. Res. 18 (2003) 1435-1440.

16) W. Zhang and A. Inoue: Mater. Trans. 45 (2004) 532-535.

17) W. Zhang and A. Inoue: Mater. Trans. 45 (2004) 1210-1213.

18) W. Zhang and A. Inoue: J. Mater. Res. 21 (2006) 234-241.

19) X. Wang, I. Yoshii, A. Inoue, Y. H. Kim and I. B. Kim: Mater. Trans., JIM 40 (1999) 1130-1136.

20) T. Zhang and A. Inoue: Mater. Trans. 43 (2002) 708-711.

21) W. Zhang and A. Inoue: Mater. Trans. 43 (2002) 2342-2345.

22) A. Inoue, W. Zhang and T. Zhang: Mater. Trans. 43 (2002) 1952-1955.

23) H. C. Yim, D. Xu and W. L. Johnson: Appl. Phys. Lett. 82 (2003) 1030-1032.

24) W. Zhang and A. Inoue: Scripta Mater. 48 (2003) 641-645.

25) D. Xu, G. Duan and W. L. Johnson: Acta Mater. 52 (2004) 3493-3497.

26) S. Pang, T. Zhang, K. Asami and A. Inoue: Mater. Trans. 43 (2002) 1771-1773.

27) C. Qin, W. Zhang, H. Nakata, H. Kimura, K. Asami and A. Inoue: Mater. Trans. 46 (2005) 858-862.

28) F. R. de Boer, R. Boom, W. C. M. Mattens, A. R. Miedema and A. K. Niessen: Cohesion in Metals, (North-Holland, Amsterdam, 1988).

29) H. A. Davies: Rapidly Quenched Metals III, Vol. 1 (edited by B. Cantor, The Metals Society. London, 1978).

30) A. Inoue: Mater. Trans., JIM 36 (1995) 866-875.

31) A. Inoue: Acta Mater. 48 (2000) 279-306.

32) S. G. Kim, A. Inoue and T. Masumoto: Mater. Trans., JIM 31 (1990) 929-934.

33) T. Zhang and A. Inoue (unpublished).

34) H. S. Chen: Rep. Prog. Phys. 43 (1980) 353-432. 